\title{
U.S. Marine ScIentific Research AND ACCESS TO FOREIGN W ATERS
}

\author{
By David A. Ross and Judith Fenwick
}

$\mathrm{W}$ - HEN planning research cruises, marine scientists often must be versed in areas once considered beyond their traditional disciplines: politics and international law. The choice of location by U.S. scientists for marine research hopefully is driven by the substance of the research itself. But geographic choices for research in recent years certainly have been colored by a mix of factors besides scientific substance, such as: the diverse maritime claims of various coastal countries, the proximity to the United States, the history of clearance activity and ease or difficulty of obtaining clearance from particular countries, and the political unpredictability of certain regions.

The marine scientist who goes to sea knows these days that there is no such thing as a simple clearance request for research in foreign waters. The term foreign naters encompasses a considerably larger geographic area than it did just a decade ago: approximately $40 \%$ of the global ocean and all of the "coastal ocean" are now politically fragmented into myriad claims for over 140 coastal states. As maritime zones have proliferated and increased in size, so has the volume of requests for clearance to conduct research in these zones.

We have been concerned with the status of access for marine scientific research (MSR) in waters under national jurisdiction from the perspective of the United States as a researching state. Law of the Sea (LOS) negotiations and the United Nations Convention on the Law of the Sea (eventually signed by 155 countries but not by the United States) set the tone for extended maritime claims, and allowed increased coastal state control over coastal and offshore waters which included jurisdiction over marine scientific research.

The anticipation was that such coastal state control under the auspices of the Law of the Sea treaty would lead to less complexity in matters of access to foreign waters, but so far it has not. There was also hope that the treaty might lead to standardized maritime claims and jurisdictions as part of customary international law. This process toward standardiza-

David A. Ross and Judith Fenwick. Department of Geology and Geophysics. Wouds Hole Oceamographic lnstitution, Woods Hole, MA 02543 tion may be occurring, but at a very slow pace. By the end of 1987, 106 coastal states (from our database of 140) have claimed jurisdiction over extended maritime zones and 78 have some form of jurisdiction over research in their extended zones (see Fig. 1, p. $38)$.

We have recently completed a study of attempts by U.S. scientists to obtain clearances in foreign waters over the sixteen-year period from 1972-87 (see Note). This progress report focuses on the eightyear period from 1979-86, which bridges the years from "extended-claim mania" (1976-78) to the recent post-LOS years. The data for 1979-86 comes from clearance requests made by U.S. scientists through the U.S. Department of State, and our analysis (Ross and Fenwick. 1988) builds upon earlier work by Knauss and Katsouros (1985.86).

The number of U.S. clearance requests and of coastal states to which requests were made for 1979 86 is shown in Table 1 . These requests represent only those accepted and forwarded by the U.S. Department of State and reflect only those U.S. marine science projects that entailed going to sea on a U.S. vessel. Oceanographic research and many international marine cooperative projects may not entail going to sea, or may involve work outside coastal state jurisdiction. or even utilize local vessels in domestic or other national coastal waters. Although we cannot consider this a full picture of international MSR involving U.S. marine scientists, the data set does represent trends in U.S./ International oceanographic research.

Table 2 summarizes denials and problems as functions of the clearance request process, and segments the data into two blocks, pre-LOS treaty (197982) and post-LOS treaty (1983-86). The first problem category reflects difficulties that originated with the coastal state from which clearance was requested (e.g., late approval resulting in cancelled or delayed research. approvals withheld because lead time requirements were not met, or approvals withheld because imposed conditions or fees were not acceptable). The second category reflects difficulties that originated in the United states (e.g., late or delayed funding, equipment problems, or inadequate lead time of requests). Although a dramatic increase in the 


\begin{tabular}{l|rrrrrrrr||c} 
& 1979 & 1980 & 1981 & 1982 & 1983 & 1984 & 1985 & 1986 & TOTALS \\
\hline Requests: & 100 & 68 & 78 & 72 & 109 & 165 & 276 & 256 & 1,124 \\
Coastal States: & 34 & 19 & 24 & 25 & 30 & 49 & 58 & 57 & 76 \\
\hline
\end{tabular}

Table 1: Namber of U.S. clearance requests and constal states to which requests were made

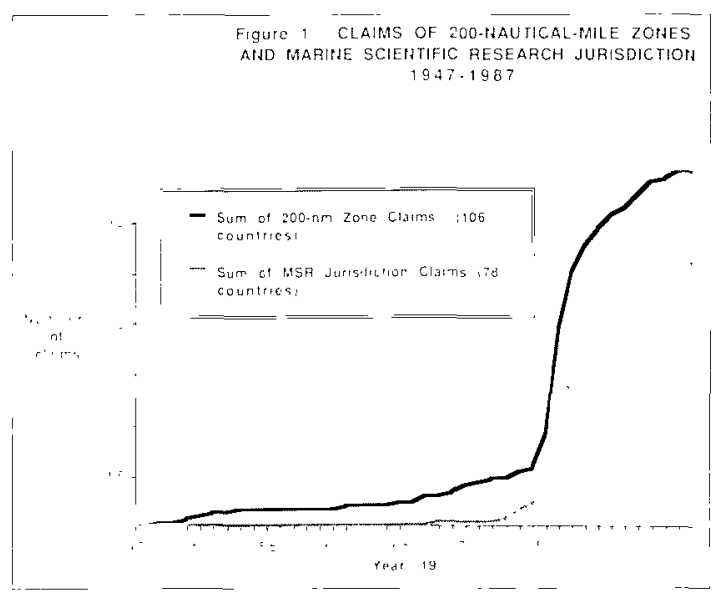

number of clearance requests and the number of coastal states occurred during 1983-86, we see a slight overall decline in the percent that denials and problems comprise during that period. By pointing to the increasing numbers in request activity, the case can be made that matters of access are more complex and difficult now than a decade ago. On the other hand, pointing to denials and problems as percents of total clearance requests. the case can be made that foreign access is slowly becoming easier to obtain.

This brings us to the juncture of historical analysis of the continued-access problem vs. active solutions to insuring that access. We can make the hypothetical cases above with the luxury of hindsight and substantiating data, to which the active researcher may respond, So what? What solutions are available to promote continuing international work? As global change programs evolve to include so many parts of the ocean and nationally claimed waters, solutions must be found.

One short-term solution to the complexities that surround planning research cruises and implementing clearance requests is to provide scientists and administrators with timely sources of information on working with foreign countries. The U.S. Department of State does an admirable job of keeping up with the flow of clearance requests and cruise obligations, but the number of requests are increasing annually.

Long-term solutions to continued access for all researching nations require international cooperation. The increase of jurisdiction over new and expanded marine territories promises new opportunities for coastal nations, but also carries the burden of increased responsibilities. A global move toward standardization of maritime claims and of state prac-

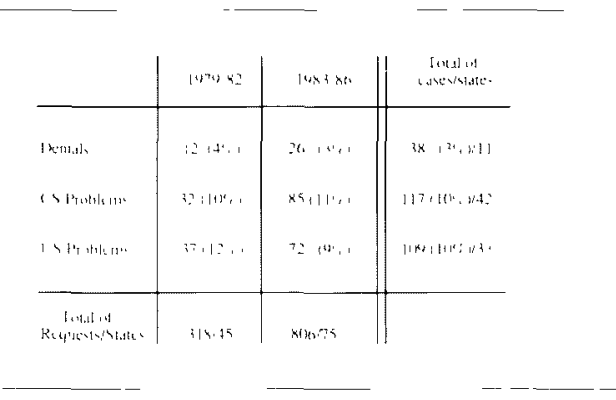

Table 2: Summary of research clearance request activity. Shown for two t-year intervals are the number of demals, the number of problems originating with the coastal state (CS). and the number of problens originating with the United States (US). For each case. the number is also given in parentheses as a percent of total requests.

tice regarding MSR jurisdiction may be idealistic, but the trends in this direction during the past decade offer some hope. Along the track toward standardization. a computer expert system for MSR clearances is being developed by researchers at the Netherlands Institute for Social and Economic Law Research with the intention of standardizing the clearance request process between all researching states and coastal states.

Oceanographic research will continue to operate in the international arena, and U.S. marine scientists inevitably will be concerned with foreign research access, especially as global research programs evolve. Yet many countries are still developing the diversity of disciplines and technologies they need to assess and manage their new maritime zones and attendant resources. Thus we hope that international cooperative programs between marine scientists, whether land-based or sea-going, will be balanced in scope to accommodate varied research agendas: global, bilateral, or scientist-to-scientist. Most important to marine scientists worldwide is the need for the legal aspects and regulations surrounding MSR to be translatable into scientific opportunities. Marine research must not be a pawn in any legal or political exercise between countries.

Additional information is available from the International Marine Science Cooperation Program (IMSCOOP), Woods Hole Oceanographic Institution. Woods Hole. MA 02543. The program. which is funded by the National Sea Grant Program. has developed a database of 140 coastal states, showing their international treaty status. marine zones and jurisdictional status, formal maritime boundaries, research jurisdiction, and U.S. research clearance 
history from 1972 to the present. Part of this database will be published this year in a report entitled "Coastal State Profiles on Marine Scientific Research." which will be distributed free to the U.S. marine science community. IMSCOOP is also working on a project to help share marine research information with developing countries, and on the establishment of an international information and assistance service on "red tides."

\section{References}

Knauss. J.A. and M. H. Katsouros, 1985: The effect of the Law of the Sea on marine scientific research in the Lnted States: Recent trends. In: The UN Convention on the Law of the Sea: Impact and lmplementution. Proceedings of the 19th Annual Conference of the Liaw of the Seal Institute. Univ. of Hawaii Press. Honolulu. 373-382.

Knauss. J.A. and M.H. Katsouros, 1986: Recent experiences of the United States in conducting marine scientific research in coastal state Exclusive Economic Zones. In: The Law' of the
Sea: What Lies Ahead?' Proceedings of the 20th Annual Conference of the Law of the Sea Institute, 1986. Univ. of Hawaii Press. Honolulu, 297-3019.

Ross. D.A. and J. Fenwick. 1988 Marme scientific research: U.S. Perspective on Jurisdiction and International Cooperation. In: New Developments in Marine Science and Technology: Economic. Legul, and Political Aspects of Change. Proceedings of the 22th Annual Conference of the Law of the Sea Institute. Univ. of Hawaii Press. Honolulu, in presss.

Note

Data for 1979-87 were obtained from yearly summaries of clearance requests prepared by Office of Marine Science and Polar Affairs. Bureau of Oceans and Intemational Environmental and Scientific Affairs. U.S. Dept. of State: data for 1972-78 come from W. S. Wooster. "Research in Troubled Waters: U.S. Research Vessel Clearance Experience. 1972-1978." Ocean Development and International Law Joumal, 9(3-4): 219-39.

\section{Acknowledgement}

This work was supported by NOAA. National Sea Grant College Program, Department of Commerce, under grant number NA86AA-D-SG(09), WHOI Sea Grant project E/L-1.

\section{RETROSPECTIVE}

As students, we are invariably reminded of Mathew Fontaine Maury, who is canonized for standardizing, collecting and publishing ships" observations of surface drift. Regarded in isolation, this seems a mundane accountant's task, not at all characteristic of a seaman's romantic or literary passions. But it is a historical misperception to limit Maury in this way. Hark back a century, open your reader. and pay attention to the recitation. Hear the Lieutenant speaking to American youth about the sea breeze in a far-away land:

"... In the summer of the southern hemisphere, the sea-breeze is more powerfully developed at Valparaiso than at any other place to which my services afloat have led me. Here regularly in the afternoon, at this season, the sea-breeze blows furiously; pebbles are torn up from the walks and whirled about the streets; people seek shelter; business is interrupted, and all communication from the shipping to the shore is cut off.

Suddenly, the winds and the sea. as if they had again heard the voice of rebuke, are hushed, and there is a great calm. The lull that follows is delightful. The sky is without a cloud, and the atmosphere is wonderfully transparent; the Andes seem to draw near; the climate, always mild and soft, becomes now doubly sweet by the contrast. The evening invites one abroad, and the population sally forth - the ladies in ball costume, for now there is not wind enough to disarrange the lightest curl....

Alone in the night-watch, after the sea-breeze has sunk to rest, I have stood on the deck under those beautiful skies, gazing, admiring, wondering. I have seen there, above the horizon at the same time, and shining with a splendor unknown to the northern latitudes, every star of the first magnitude ... The stillness below is in harmony with the silence above; and one almost fears to speak lest the harsh sound of the human voice ... drown the music that fills the soul."

Mathew Fontaine Maury

Excerpt from "Land and Sea-Breezes."

Barnes' New National Fifth Reader

A.S. Barnes and Co., New York,

(C) 1884

These are not the words of a dispassionate fact-collector. Some of the soul's music may have failed to impress the Fifth Reader's impounded audiences, but the legato passage is not lost on those who also have stood alone in the night-watch and heard the clear, thin notes.

$-D A B$ 